\title{
Honey bees and their brood: a potentially valuable resource of food, worthy of greater appreciation and scientific attention
}

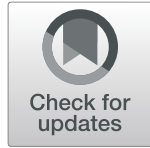

\author{
Sampat Ghosh ${ }^{1 *} \mathbb{D}$, Victor Benno Meyer-Rochow ${ }^{1,2}$ and Chuleui Jung ${ }^{1,3}$
}

\begin{abstract}
Despite the consumption of bee brood in several parts of the world, particularly in the tropical areas, the practice has received comparatively little attention. We have reviewed all the available information on the nutrient composition and functional properties of different developmental stages of honey bee workers belonging to different species and subspecies. Noticing the competent nutrient composition of, in particular, honey bee brood, pupae, and prepupae, we suggest that they could be a potential source of human nutrition as well as animal feed. Moreover, drone brood is an ideal candidate for use as a food or as food ingredient. However, to analyze the functional properties of different honey bee species remains a task for further analysis.
\end{abstract}

Keywords: Entomophagy, Protein, Amino acid, Minerals, Functional properties, Apiary, Bee products

\section{Introduction}

Since time immemorial, human civilizations enjoyed a close association with honey bees. According to archeological evidence found in Neolithic sites of Europe and northern Africa, humans have been exploiting honey bees and their products for at least 9000 years (RoffetSalque et al. 2015). Humans gathered honey as part of their food and used it for medicinal purposes, as mentioned already in the age-old literatures of the Ayurveda, Talmud, Bible, etc. The reason why honey bees were appreciated was not only related to the use of their honey as food and medicine but also beeswax, too, had its place and applications in the ancient cultures (d'Errico et al. 2012). Gradually, humans developed the domestication process of the honey bee and improved and expanded the number of useful hive products beyond honey and beeswax to include bee pollen, royal jelly, propolis, and bee venom, all of which are given attention to, because of their functional properties (Ghosh et al. 2021a).

\footnotetext{
* Correspondence: sampatghosh.bee@gmail.com

${ }^{1}$ Agriculture Science and Technology Research Institute, Andong National University, Andong, Republic of Korea

Full list of author information is available at the end of the article
}

Besides, honey bees are also considered to be the main pollinating workhorse of the insect world, accounting, along with other pollinators, for $35 \%$ of the food production globally (Klein et al. 2007).

However, despite the practice of consuming bee brood in several parts of the world, particularly in the tropical areas, this kind of food has received comparatively little attention as a human food item. To cite a few examples, Australian Aboriginal people consume the honey plus specimens of native bees as food (Cherry 1991); the Hazda people of Tanzania do not remove bee larvae from the combs that they eat (Murray et al. 2001) and in Thailand more than 10,000 colonies of Apis florea are annually harvested by "bee hunters" as people consume larvae, pupae, and the honey together (Wongsiri et al., 1997). The use of honey bee brood as food is also common in Mexico (Ramos-Elorduy et al. 1997), Bali (TorreBueno 1944, cf. Hocking and Matsumura 1960), Ecuador (Onore 1997), Zambia (Mbata 1995), Senegal (Gessain et al. 1975, cited in Jensen et al. (2019)) and China (ZhiYi 1997). Therefore, in order to recommend the potential role of honey bees as human food and animal feed, it is essential to investigate their nutrient content.

(c) The Author(s). 2021 Open Access This article is licensed under a Creative Commons Attribution 4.0 International License, which permits use, sharing, adaptation, distribution and reproduction in any medium or format, as long as you give appropriate credit to the original author(s) and the source, provide a link to the Creative Commons licence, and indicate if changes were made. The images or other third party material in this article are included in the article's Creative Commons licence, unless indicated otherwise in a credit line to the material. If material is not included in the article's Creative Commons licence and your intended use is not permitted by statutory regulation or exceeds the permitted use, you will need to obtain permission directly from the copyright holder. To view a copy of this licence, visit http://creativecommons.org/licenses/by/4.0/. 


\section{Diversity of honey bee}

Honey bee belongs to the insect order of the Hymenoptera, family Apidae, subfamily Apinae, and tribe Apini. The Apini comprises only a few species of which four of them, namely, Apis mellifera, A. cerana, A. dorsata, and A. florea are dominant (Ruttner 1988). The European (or Western) honey bee A. mellifera is the most commonly used species worldwide in commercial beekeeping practices. Instead, the other three social bee species remain as wild bees, with the exception of a few cases of cultivated $A$. cerana. However, regarding entomophagy, i.e., the consumption of bees and their developmental stages as food, there is according to the existing literature no such species-biased selection especially in connection with the bee brood. Therefore, to investigate the nutrient composition of this resource involving all four major species seemed a task in need to be investigated.

Honey bees are holometabolous insects, going through four stages in their life cycle, i.e., egg, larva, pupa, and adult. Furthermore, as social insects they have three different castes distinguishable as queens, workers, and drones. It is important to identify and select the most suitable developmental stage or stages if one wishes to recommend them as a food item for humans. Among the different developmental stages, pupae or prepupae (often referred to as "pharates") can be ideal candidates as hymenopteran larvae do not void their gut content until 2-3 days before pupation (DeFoliart 1995). Because of the honey bee's enormous importance in pollinating crops and the fact that worker bees alone are involved in the process, it is necessary to determine to what extent the production of worker pupae could be maximized (if the focus is on worker bees as food) without reducing honey production or stressing the adult population. On the other hand, drones by comparison have limited roles to play in the socio-biology of honey bees and are only needed for reproduction and to some extent in the thermoregulation of the hive environment and removal of parasites like Varroa. Also, through a "compensatory egg-laying" process the size of drone populations can be manipulated to a suitable degree for large scale production.

\section{Literature review of published works on the nutritional composition of honey bees and their brood}

Despite the documented use of honey bee brood as food for humans, data on nutrient composition as well as the functional compounds in the bees and their broods are still not well defined. However, estimating the nutrient content of different developmental stages had not remained completely untouched in the past. To the best of our knowledge, Strauss in 1911, for example, appears to have been the first (cf., Hocking and Matsumura
(1960)), to demonstrate chemical compositional differences between worker and drone honey bees of different developmental stages. In emerging honey bee workers during the first 5 days, a considerable increment of protein content was reported to occur and to account for about $50 \%$ of body weight thereafter (Strauss 1911; De Groot 1950). De Groot (1950) showed that temperature and feeding both influence nitrogen content of young workers and in Haydak, 1959 noticed that the changes in nitrogen content on the basis of dry weight affected different body parts (e.g., head, abdomen, and thorax) in individuals of different ages. The observation agreed with the earlier results that nitrogen content of body parts of adult honey bees (head and thorax of drones and queens; heads and abdomens of workers) reached their highest concentration at a certain period and thereafter declined as the insect became older.

Hocking (1957) carried out a few experiments on cooking (e.g., shallow frying with butter and deep-frying in vegetable fat), experimented with freezing methods and addressed the problem of the acceptance of honey bee larvae and pupae as food by potential consumers. Hocking and Matsumura (1960) reported nutrient content of honey bee brood on the wet weight basis. Respective protein contents of mature larvae and pupae were reported as 15.4 and $18.2 \%$ on wet weight basis while their fat contents were 3.71 and 2.39\% (Hocking and Matsumura 1960). The study showed that the protein content of honey bee brood was comparable, if not higher, to that of beef, milk, and egg yolk. Omizek et al. (1985) estimated protein and amino acid composition of dried honey bees and bee protein concentrate, while $\mathrm{Hu}$ and Li (2001) analyzed proximate nutrient composition and amino acid profiles up to the 20th day of aging worker larvae and pupae. Finke (2005) came up with a detailed account on the nutrient composition of honey bee brood although his broods were not separated based on developmental stages, but consisted mostly of pupae and less than 10\% mature larvae. In a recent study, Bamidele et al. (2021) estimated the nutritional composition of honey bees from different ecological regions of Nigeria.

In most of these earlier chemical composition and nutrient studies, it had been $A$. mellifera that had received the largest attention. We have now carried out a series of investigations on the nutrient composition of different honey bee species and subspecies at different developmental stages (Ghosh et al. 2016, 2020a, 2020b, 2020c; Ghosh et al., 2021b) and are presenting the data in this paper.

\section{Nutrient potential of honey bee}

\section{Protein and amino acid composition}

Protein is generally considered the most important nutrient and a reliable indicator in assessments of the 
quality of a food. On dry matter basis, respective protein content of larval, pupal, and adult A. mellifera workers was found to be 35.3, 45.9, and 51\% (Ghosh et al. 2016). These values are in agreement with previous reports (Strauss 1911; De Groot 1950). A somewhat higher value for protein $(56.8 \%)$ of adult workers was reported by Ozimek et al. (1985). Bamidele et al. (2021) reported their protein content of $A$. mellifera adansonii to be within the range of 7.4 to $8.7 \%$ on fresh weight basis, which upon conversion to a dry weight datum turns out to be $37.1 \%$, which is less than what earlier researchers had reported. Finke (2005) estimated the protein content of $94 \mathrm{~g}$ per $\mathrm{kg}$ of bee brood to be about $40.5 \%$ on the dry matter basis, which is in agreement with the reports published by Ghosh et al. (2016), Hu and Li (2001). Hocking and Matsumura (1960) reported higher protein contents of mature larvae (15.4\% wet weight basis) and pupae (18.2\% wet weight basis). On the other hand, protein content of $A$. mellifera drone pupae was found to be $11.1 \%$ on wet weight basis, i.e., $42.9 \%$ on dry weight basis (Kim et al. 2018), which is in agreement with the value of total amino acids for drone pupae (Ghosh et al. 2020c).

Protein is made up of amino acids and therefore we investigated the amino acid composition of honey bees of different species and different developmental stages. Table 1 represents the amino acid composition of four different honey bee species. Altogether 17 amino acids were determined, but tryptophan was not recovered and sulfur-containing amino acids, e.g., cysteine and methionine, were not entirely assessable presumably because of acid hydrolysis processes. However, the amino acid distribution patterns follow similar trends (Ozimek et al. 1985; $\mathrm{Hu}$ and Li 2001; Finke 2005; Kim et al. 2018; Ghosh et al. 2016, 2020a, 2020b, 2020c; Ghosh et al., 2021b) and leucine was consistently the most abundant among the essential amino acids, while glutamic and aspartic acid were predominating overall. Of the total protein content of the pupae of different honey bee species, essential amino acid amounts ranged between 40.3 and $45.9 \%$ and non-essential amino acids ranged from 54.1 to $59.7 \%$ (calculated from Table 1). This was comparable, if not superior, to soybean, which contains 41 and $59 \%$ of total protein as essential and non-essential amino acids. Kim et al. (2020a) showed that the amino acid composition of drone pupal protein hydrolysate varied widely (total amino acids content: 100.5 to $470.8 \mathrm{mg}$ / g protein hydrolysate) with the use of different enzymes, namely, alcalase, neutrase, flavourzyme, and combinations of them.

Amino acid composition and, therefore, the protein content generally, depend on the developmental stage and physiological as well as environmental condition. We found an increasing trend of protein (i.e., total
Table 1 Amino acid composition ( $\mathrm{g} / 100 \mathrm{~g}$ dry matter based) of different developmental stages of honey bee workers belonging to the genus Apis

\begin{tabular}{|c|c|c|c|c|c|c|c|}
\hline & \multicolumn{2}{|l|}{$A M$} & \multicolumn{2}{|l|}{$A C$} & \multicolumn{2}{|l|}{$A D$} & \multirow{2}{*}{$\begin{array}{l}\text { AF } \\
P\end{array}$} \\
\hline & $P$ & A & $P$ & A & $P$ & A & \\
\hline$\overline{\mathrm{Va}} \mathrm{l}^{\mathrm{a}}$ & 2.4 & 2.7 & 3.1 & 3.7 & 2.2 & 3.3 & 2.1 \\
\hline$\| e^{a}$ & 2.3 & 2.2 & 2.4 & 3.2 & 1.7 & 2.6 & 1.7 \\
\hline $\mathrm{Leu}^{\mathrm{a}}$ & 3.2 & 3.8 & 4.4 & 5.2 & 3.3 & 4.5 & 3.3 \\
\hline Lys $^{a}$ & 3.0 & 2.6 & 3.0 & 4.2 & 2.2 & 3.3 & 2.3 \\
\hline $\operatorname{Thr}^{\mathrm{a}}$ & 1.9 & 2.1 & 2.2 & 2.4 & 1.7 & 1.9 & 1.7 \\
\hline $\mathrm{His}^{\mathrm{a}}$ & 1.1 & 1.0 & 1.3 & 1.1 & 1.0 & 1.2 & 1.0 \\
\hline$S A A^{a}$ & 0.4 & 0.7 & 2.4 & 4.3 & 1.9 & 5.1 & 1.7 \\
\hline $\mathrm{AAA}^{\mathrm{a}}$ & 2.2 & 2.2 & 4.0 & 4.2 & 2.8 & 4.3 & 3.3 \\
\hline Arg & 2.3 & 2.3 & 2.5 & 3.1 & 1.9 & 2.5 & 1.9 \\
\hline Asp & 3.5 & 3.2 & 6.3 & 2.1 & 5.2 & 2.7 & 3.7 \\
\hline Ser & 2.0 & 2.3 & 2.4 & 3.0 & 1.9 & 2.7 & 1.8 \\
\hline Glu & 8.4 & 6.0 & 5.3 & 8.5 & 4.3 & 7.3 & 5.0 \\
\hline Gly & 2.5 & 3.0 & 3.7 & 4.3 & 2.9 & 4.6 & 2.2 \\
\hline Ala & 2.9 & 3.8 & 4.9 & 6.0 & 3.3 & 5.0 & 2.9 \\
\hline Pro & -- & -- & 3.4 & 3.8 & 2.7 & 4.7 & 2.7 \\
\hline Others & 2.8 & 1.5 & -- & -- & -- & & -- \\
\hline Total & 40.9 & 39.4 & 51.3 & 59.0 & 39.0 & 55.7 & 37.3 \\
\hline
\end{tabular}

Abbreviations: AM Apis mellifera, AC Apis cerana, AD Apis dorsata, AF Apis florea, $P$ pupa, $A$ adult

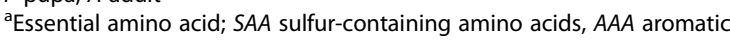
amino acids

Data obtained for AM: Ghosh et al. 2016; for pupa of AC and AD: Ghosh et al. 2020a, and AF: Ghosh et al. 2020b. Data for adult worker of AC and AD is from present study

amino acids) content with the higher developmental stages of worker honey bees in both $A$. cerana and $A$. dorsata, although in case of $A$. mellifera, the total amino acid content of their adults was a little less than that of their pupae. The adults require amino acids mainly for somatic functions including enzyme production, peptide signaling, tissue building and repair, and immune responses (Millward et al. 1997), but the higher requirements of amino acids for younger bees shifts as they age and become foragers (Paoli et al. 2014). The similar amino acid contents of $A$. mellifera adults and pupae are likely the result of their close proximities in age. Our adult population consisted of hive workers, which could not be separated according to their precise ages and hive duty stages.

The requirement of nutrients including protein and amino acids varies and is based on the honey bee's agedependent physiological functionality. Nurse bees provision future worker larvae for a limited time and queen larvae continually with their glandular secretions of royal jelly. Therefore, the production of royal jelly is a metabolic demand for the larvae (Paoli et al. 2014). Proline as fuel for foragers is important (Micheu et al. 
2000). On the other hand, as the adult worker bees are overwhelmingly sterile, their nutritional requirement is less than that of queen or drone bee larvae. Table 2 represents the amino acid compositions of different developmental stages of the pupae of various A. mellifera subspecies. An increasing trend of protein content was noticeable in connection with the developmental stages of the drones.

Amino acids play critical roles in the human nutrition and metabolism. Branched aliphatic side-chaincontaining amino acids, i.e., leucine, isoleucine, and valine, are ubiquitous nitrogen donors and generally act as metabolic fuel. Lysine is the precursor of carnitine, which is required for the transport of fatty acids. Lysine is important as it is often lacking in cereal-based diets. Methionine acts as a donor and acceptor of methyl groups, while histidine functions as a precursor for the synthesis of histamine. Phenylalanine and tyrosine are precursors for tyramine, dopamine, adrenaline (epinephrine), and noradrenaline (norepinephrine). Histidine and $\beta$-alanine are needed to synthesize carnosine. In this context, it is worth mentioning that non-essential amino acids are also very important in regard to the regular bodily metabolism. Glutamate is a general transporter of four-carbon units and also a facilitator of the $\gamma$ aminobutyric acid synthesis. Glycine and serine are donors of methylene and hydroxymethylene groups respectively. Glycine also donates nitrogen for haem synthesis. Aspartate and arginine are involved in the urea cycle.

The amino acid contents of honey bee pupal protein with the exception of sulfur-containing amino acids satisfies the ideal protein requirements for human subjects as recommended by WHO/FAO/UNU (FAO (Food and Agriculture Organization of the United Nations), 2013) (Fig. 1a). Similarly, developmental stages of drone bee pupae satisfy the ideal protein pattern except for a few cases of histidine and sulfur-containing amino acids (Fig. 1b).

\section{Fat and fatty acid composition}

Fatty acids and thus fat, generally, are the densest dietary source of energy. Besides, they are also important for their structural roles in cell membranes, regulating and signaling roles for hormones (i.e., steroids), aiding absorption, and increasing bioavailability of several nutrients. Fat contents of A. mellifera larvae, pupae, and adults were found 14.5, 16.0, and $6.9 \%$ on the basis of dry matter (Ghosh et al. 2016). Ozimek et al. (1985) found that the fat content of whole dried worker honey bees accounted for $7.5 \%$. Finke (2005) reported a fat content of $47 \mathrm{~g}$ per $\mathrm{kg}$ of bee brood, which is about $20.3 \%$ of the dry weight. However, some dietary fats, especially saturated ones, are potentially significant risk factors for obesity and other related chronic

Table 2 Amino acid composition ( $\mathrm{g} / 100 \mathrm{~g}$ dry matter based) of different developmental stages of honey bee drones belonging to different Apis mellifera subspecies

\begin{tabular}{|c|c|c|c|c|c|c|c|c|c|c|c|c|c|}
\hline & \multicolumn{3}{|l|}{ AMM } & \multicolumn{3}{|l|}{ AMC } & \multicolumn{4}{|l|}{ AML } & \multicolumn{3}{|l|}{ AMB } \\
\hline & $\overline{P P}$ & EP & LP & $\overline{P P}$ & EP & LP & $\overline{E P}$ & LP & EA & A & $\overline{P P}$ & LP & $A$ \\
\hline$\overline{\mathrm{Va}} \mathrm{l}^{\mathrm{a}}$ & 1.9 & 2.2 & 2.4 & 1.8 & 2.2 & 2.5 & 2.6 & 3.0 & 4.1 & 4.2 & 2.9 & 3.0 & 3.8 \\
\hline$\| e^{a}$ & 1.6 & 1.9 & 2.2 & 1.6 & 1.9 & 2.2 & 2.1 & 2.4 & 3.2 & 3.3 & 2.4 & 2.6 & 3.3 \\
\hline Leu $^{a}$ & 2.7 & 3.1 & 3.5 & 2.6 & 3.2 & 3.6 & 3.5 & 4.1 & 5.5 & 5.7 & 4.0 & 4.3 & 5.5 \\
\hline Lys $^{a}$ & 2.4 & 2.8 & 3.1 & 2.3 & 2.8 & 3.2 & 3.0 & 3.5 & 4.4 & 4.6 & 3.5 & 3.7 & 4.4 \\
\hline $\operatorname{Thr}^{\mathrm{a}}$ & 1.4 & 1.5 & 1.7 & 1.3 & 1.6 & 1.7 & 1.9 & 1.9 & 3.2 & 2.7 & 1.9 & 1.6 & 2.0 \\
\hline $\mathrm{His}^{\mathrm{a}}$ & 0.8 & 0.9 & 1.1 & 0.8 & 0.9 & 1.1 & 0.9 & 1.1 & 1.4 & 1.4 & 1.2 & 1.3 & 1.6 \\
\hline$S A A^{a}$ & 1.0 & 1.4 & 1.8 & 0.6 & 0.3 & 1.1 & 0.4 & 0.7 & 2.3 & 2.7 & 1.4 & 1.5 & 3.4 \\
\hline $\mathrm{AAA}^{\mathrm{a}}$ & 3.0 & 3.4 & 3.9 & 3.0 & 3.4 & 3.8 & 4.0 & 4.8 & 5.3 & 5.3 & 4.6 & 4.9 & 5.1 \\
\hline Arg & 1.7 & 2.0 & 2.3 & 1.7 & 2.1 & 2.3 & 2.2 & 2.6 & 3.4 & 3.6 & 2.2 & 2.5 & 3.7 \\
\hline Asp & 2.4 & 2.8 & 3.0 & 2.4 & 2.8 & 2.8 & 2.5 & 2.7 & 3.2 & 3.4 & 3.2 & 3.2 & 3.7 \\
\hline Ser & 1.4 & 1.7 & 2.0 & 1.4 & 1.6 & 1.9 & 1.8 & 2.1 & 3.2 & 2.9 & 2.0 & 2.4 & 2.9 \\
\hline Glu & 6.6 & 7.6 & 8.1 & 6.3 & 7.7 & 7.4 & 10.0 & 10.6 & 12.2 & 12.4 & 7.9 & 8.8 & 8.7 \\
\hline Gly & 1.6 & 1.9 & 2.4 & 1.5 & 1.9 & 2.6 & 2.1 & 2.8 & 4.6 & 4.4 & 2.3 & 2.7 & 4.2 \\
\hline Ala & 1.5 & 2.0 & 2.5 & 1.5 & 2.0 & 2.9 & 2.6 & 3.4 & 5.8 & 6.0 & 2.4 & 2.9 & 5.3 \\
\hline Pro & 2.8 & 3.3 & 3.6 & 2.4 & 3.0 & 3.7 & 3.0 & 3.6 & 4.6 & 4.7 & 1.6 & 1.5 & 2.3 \\
\hline Total & 32.8 & 38.4 & 43.4 & 31.1 & 37.4 & 42.5 & 42.6 & 49.4 & 66.3 & 67.0 & 43.5 & 46.6 & 59.7 \\
\hline
\end{tabular}

Abbreviations: AMM Apis mellifera mellifera, AMC Apis mellifera carnica, AML Apis mellifera ligustica, AMB Apis mellifera buckfast, PP prepupa, EP early pupa, LP late pupa, $A$ adult

${ }^{a}$ Essential amino acid; $S A A$ sulfur-containing amino acids, $A A A$ aromatic amino acids

Data obtained for AML and AMB: Ghosh et al. 2020c; AMM and AMC: Ghosh et al. 2021b 


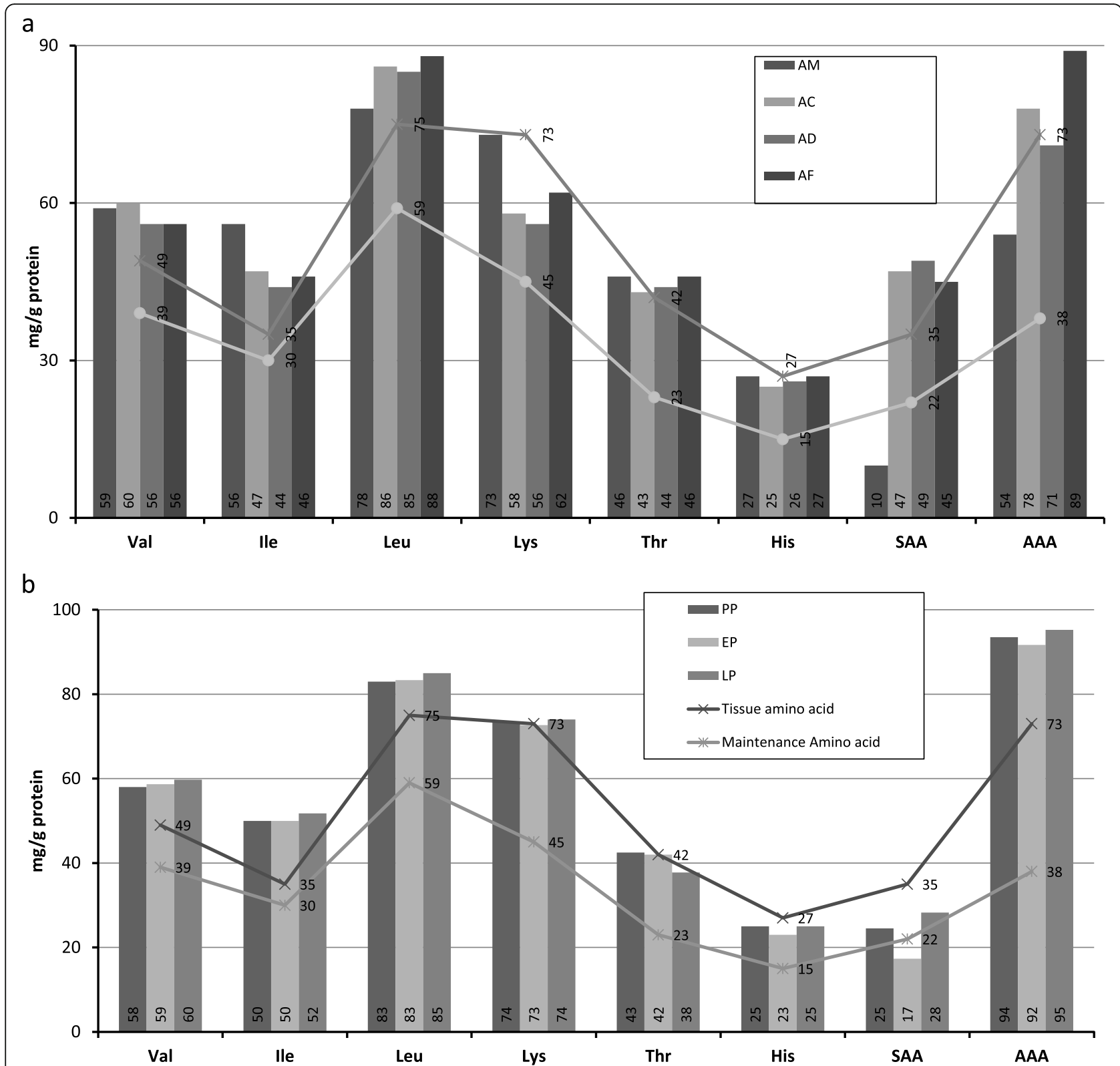

Fig. 1 Scoring pattern of protein contained from (a) worker pupa of different Apis species (AM Apis mellifera, AC Apis cerana, AD, Apis dorsata, AF, Apis florea) (b) different pupal (PP, prepupa; EP, early pupa; LP, late pupa) stages of drone honey bee taking the averange value of different Apis mellifera subspecies. Scoring pattern was calculated by taking the tissue amino acid pattern and maintenance amino acid pattern into consideration. The values were amended from the WHO/FAO/UNU 2007 report (FAO 2013)

degenerative diseases. Based on their degree of saturation, fatty acids are categorized into three groups, namely, saturated (SFA), monounsaturated (MUFA), and polyunsaturated fatty acids (PUFA). A high consumption of SFAs is not desirable, because of their linkage with obesity and related disorders. On the other hand, MUFA and PUFA are regarded as beneficial and seen as health promoters, exerting cardio-protective effects, alleviating atherosclerosis problems, and improving other debilities. Therefore, in order to investigate the potential role of fats from honey bees, it was necessary to examine their fatty acid profiles.

Tables 3 and 4 represent fatty acid compositions of different developmental stages of worker honey bees and drones. Total fatty acid contents of the pupal stages of different species of honey bee workers were found to fall within the range of 5.5 to $7.2 \mathrm{~g} / 100 \mathrm{~g}$. A lower fat content in comparison to the conventional foods of animal origin is an advantage for the use of honey bees as human food. It has been shown that the total fatty acid 
Table 3 Fatty acid composition (mg/100 $\mathrm{g}$ dry matter based) of different developmental stages of honey bee workers belonging to the genus Apis

\begin{tabular}{|c|c|c|c|c|c|c|c|c|}
\hline & \multicolumn{2}{|l|}{$A M$} & \multicolumn{2}{|l|}{$A C$} & \multicolumn{2}{|l|}{$A D$} & \multicolumn{2}{|l|}{$\mathrm{AF}$} \\
\hline & $P$ & A & $P$ & A & $\mathbf{P}$ & A & $\mathbf{P}$ & A \\
\hline \multicolumn{9}{|c|}{ Saturated fatty acids (SFA) } \\
\hline C12:0 & 24.6 & 4.5 & 30 & 20 & 30 & 10 & 20 & 20 \\
\hline C13:0 & ND & ND & 10 & 10 & ND & 10 & ND & 10 \\
\hline C 14:0 & 157.5 & 9.8 & 190 & 80 & 200 & 30 & 130 & 80 \\
\hline C16:0 & 1942.2 & 250.8 & 1990 & 770 & 2060 & 450 & 2540 & 1650 \\
\hline C18:0 & 696.8 & 162.4 & 670 & 510 & 730 & 450 & 630 & 520 \\
\hline C20:0 & ND & ND & 40 & 40 & 30 & 30 & 30 & 40 \\
\hline Subtotal & 2821.1 & 437.9 & 2930 & 1430 & 3050 & 980 & 3350 & 2320 \\
\hline \multicolumn{9}{|c|}{ Monounsaturated fatty acids } \\
\hline C16:1 & 31.1 & 44.7 & 30 & 50 & 20 & 40 & 30 & 30 \\
\hline C18:1 & 2632.1 & 785.5 & 3160 & 2440 & 2950 & 1910 & 3420 & 2670 \\
\hline C20:1 & 41.6 & 333.4 & 150 & 190 & 110 & 130 & 310 & 290 \\
\hline Subtotal & 2704.8 & 1163.6 & 3340 & 2680 & 3080 & 2080 & 3760 & 2990 \\
\hline \multicolumn{9}{|c|}{ Polyunsaturated fatty acids } \\
\hline C18:2 & ND & 135.5 & 60 & 110 & 50 & 70 & 70 & 60 \\
\hline C18:3 & ND & ND & 10 & 10 & ND & ND & 10 & ND \\
\hline Subtotal & ND & 135.5 & 70 & 120 & 50 & 70 & 80 & 60 \\
\hline Total & 5525.9 & 1737.0 & 6340 & 4230 & 6180 & 3130 & 7190 & 5370 \\
\hline
\end{tabular}

Abbreviations: AM Apis mellifera, AC Apis cerana, AD Apis dorsata, AF Apis florea, $P$ pupa, $A$ adult

Data obtained for AM: Ghosh et al. 2016; for pupa of AC and AD: Ghosh et al. 2020a, and AF: Ghosh et al. 2020b

content followed a decreasing trend, unlike amino acids, with the developmental stages of honey bees. Fats, besides trehalose and proline, are major substrates providing energy required for flight (Arrese and Soulages 2010) and this could be one possible reason behind the differences of fat (i.e., total fatty acids) content in adults and the premature stages. Moreover, in regard to the small amount of PUFA, not every insect is capable of synthesizing linoleic acid and therefore a thorough investigation of fatty acid synthesis in the honey bee remains to be carried out.

\section{Carbohydrate content}

Carbohydrate is another group of macronutrient. Insects especially the adults and crustaceans are a good source of chitin, a natural polysaccharide composed of repeating $\beta(1,4)-\mathrm{N}$-acetylglucosamine units which form cuticle, accounting for $5-20 \%$ of the total body weight (Paoletti et al. 2007). Honey bees are not an exception. Ghosh et al. (2016) estimated the carbohydrate content of honey bees to be within the range of 30.6 to $46.1 \%$ depending on the developmental stage, although the exact composition of the carbohydrate present remains uninvestigated. Nemtsev et al. (2001) estimated the chitin amount of dead and dried bees to be as high as $10-12 \%$; he then later isolated the chitin and chitosan from honey bees and characterized the substance (Nemtsev et al. 2004). Draczynski (2008) used honey bee corpses as a source of chitin.

However, human organisms were not thought of producing chitinase until 1994 and, therefore, chitin was considered as non-digestible component (DeFoliart 1992; Muzzarelli et al. 2012). Based on this concept, chitin is reduced in the diet and a low intake of chitin in the diet might have reduced selective pressure on chitinase genes which probably resulted in the loss of catalytic efficiency (Paoletti et al. 2009). With the discovery of a chitinase enzyme in humans (Hollak et al., 1994; Boot et al. 1998; Chang et al. 2001; Paoletti et al. 2007), chitin and chitin-bearing foods including insects (and mushrooms) become a subject of interest. Chitin and its derivatives are also potential prebiotics for human gut microbiota (Lopez-Santamarina et al. 2020; Kipkoech et al. 2021).

\section{Minerals content}

Minerals are essential micronutrients playing several critical physiological functions including providing structural integrity, and catalytic ability. They are generally obtained from the diet. In 1990s, "micronutrient deficiency" became an important issue in the food policy especially in the context of developing world (Kimura 2013). Iron is a critical point of concern, especially in developing countries. Haddad (1999) reported that the iron content of the Asian diet decreased due to "the green revolution" and it has been replaced by foods like beans, peas, and cereals. The most vulnerable section of the population suffering from iron deficiency or anemia are women, especially those lactating and of childbearing age. On the other hand, zinc plays vital roles in many metabolic pathways including DNA replication, transcription, and protein synthesis. Thus, the minerals, of nutritional importance, are important in examinations of the value of a food item.

Tables 5 and 6 represent the mineral contents of worker and drone bees, respectively. Except for sodium, all other investigated minerals were found to be higher in honey bee pupae than in conventional meats (Fig. 2). For almost all minerals, adult A. mellifera honey bees contained higher amounts than their pupae did with the exception of potassium. The variation of mineral contents is also subject to different ecological and environmental conditions. Phosphorus was the most abundant mineral followed by potassium. From the nutritional standpoint, high potassium and low sodium content could exhibit nutritional benefits, especially for the section of the human population suffering from hypertension. A significant proportion of the recommended 
Table 4 Fatty acid composition (mg/100 g dry matter based) of different developmental stages of honey bee drones belonging to different Apis mellifera subspecies

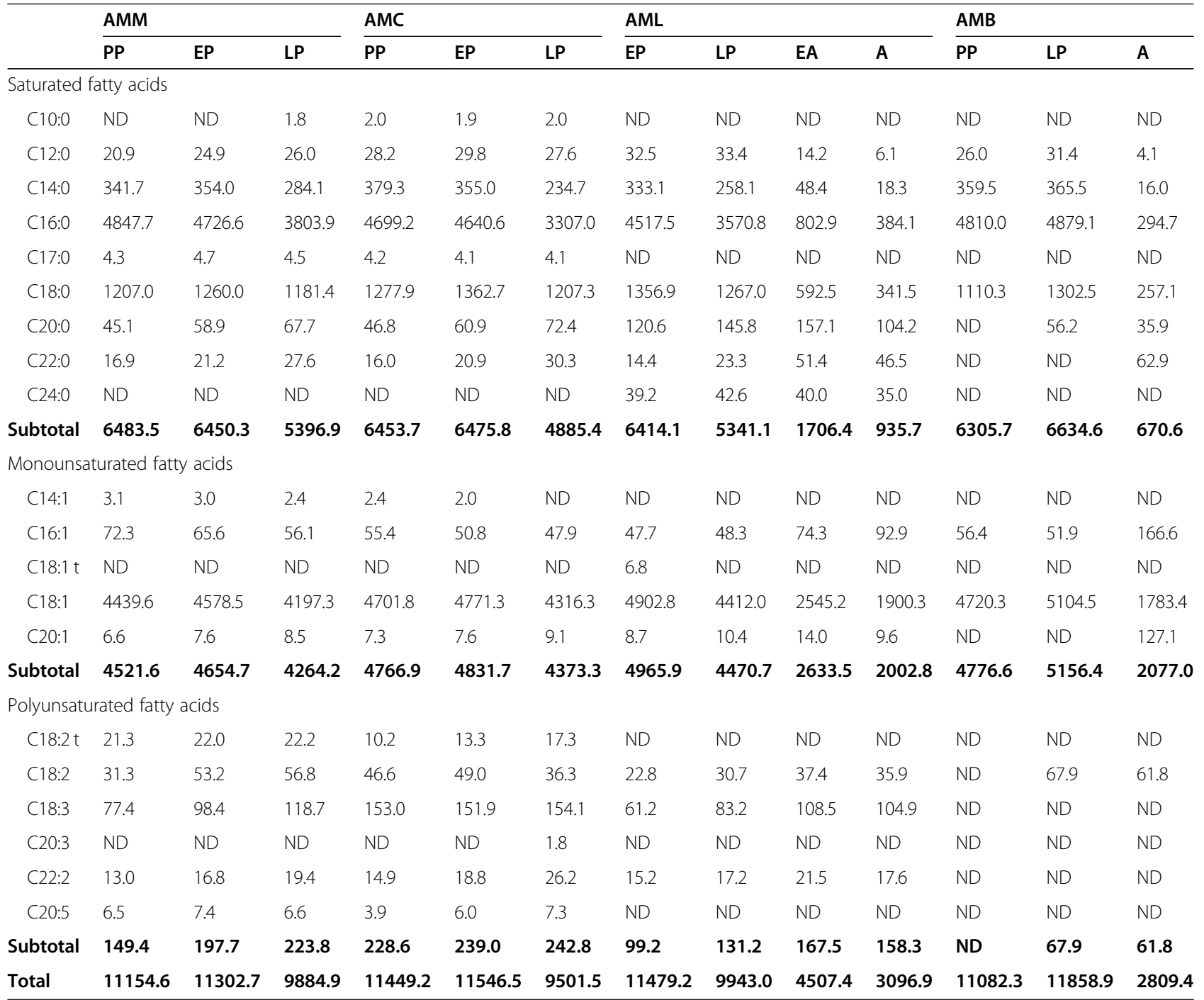

Abbreviations: AMM Apis mellifera mellifera, AMC Apis mellifera carnica, AML Apis mellifera ligustica, AMB Apis mellifera buckfast, PP prepupa, EP early pupa, LP late pupa, $E A$ early adult, $A$ adult

Data obtained for AML and AMB: Ghosh et al. 2020c; AMM and AMC: Ghosh et al. 2020b

Table 5 Minerals content (mg/100 g dry matter based) of different developmental stages of honey bee workers belonging to the genus Apis

\begin{tabular}{|c|c|c|c|c|c|c|c|c|}
\hline & \multicolumn{2}{|l|}{ AM } & \multicolumn{2}{|l|}{$A C$} & \multicolumn{2}{|l|}{$A D$} & \multicolumn{2}{|l|}{ AF } \\
\hline & $P$ & $A$ & $P$ & $A$ & $P$ & $A$ & $P$ & $A$ \\
\hline Calcium & 97.0 & 222.9 & 62.9 & 91.1 & 68.9 & 99.2 & 67.1 & 80.0 \\
\hline Magnesium & 193.9 & 201.7 & 104.3 & 148.8 & 103.4 & 144.7 & 117.2 & 144.2 \\
\hline Phosphorus & 900.0 & 860.1 & 931.5 & 1283.9 & 905 & 1187.9 & 1105 & 1368.9 \\
\hline Sodium & 60.8 & 75.6 & 44.4 & 77.1 & 48.6 & 67.8 & 72.9 & 84.9 \\
\hline Potassium & 2207.3 & 1585.4 & 1153.2 & 1538.8 & 1136.6 & 1573.9 & 1235 & 1519.3 \\
\hline Iron & 15.3 & 37.7 & 7.1 & 11.1 & 5.8 & 8.9 & 7.9 & 9.4 \\
\hline Zinc & 11.7 & 14.0 & 7.7 & 12.9 & 6.4 & 9.5 & 7.7 & 8.7 \\
\hline Copper & 3.7 & 4.6 & 1.2 & 1.9 & 1.1 & 1.6 & 2.9 & 2.2 \\
\hline
\end{tabular}

Abbreviations: AM Apis mellifera, AC Apis cerana, AD Apis dorsata, AF Apis florea, $P$ pupa, $A$ adult

Data obtained for AM: Ghosh et al. 2016; for pupa of AC and AD: Ghosh et al. 2020a, and AF: Ghosh et al. 2020b 
Table 6 Minerals content (mg/100 g dry matter based) of different developmental stages of honey bee drones belonging to different Apis mellifera subspecies

\begin{tabular}{|c|c|c|c|c|c|c|c|c|c|c|c|c|}
\hline & \multicolumn{3}{|l|}{ AMM } & \multicolumn{3}{|l|}{ AMC } & \multicolumn{3}{|l|}{ AML } & \multicolumn{3}{|l|}{ AMB } \\
\hline & PP & EP & LP & PP & EP & LP & EP & LP & A & PP & LP & A \\
\hline Calcium & 39.3 & 40.1 & 43.3 & 34.0 & 37.9 & 46.1 & 43.7 & 49.3 & 66.2 & 34.2 & 38.7 & 60.7 \\
\hline Magnesium & 70.2 & 75.3 & 85.8 & 65.9 & 74.3 & 88.4 & 82.9 & 95.0 & 123.2 & 68.1 & 81.9 & 121.5 \\
\hline Sodium & 8.1 & 8.7 & 9.9 & 7.8 & 7.0 & 10.3 & 7.3 & 8.5 & 11.3 & 30.1 & 38.0 & 79.5 \\
\hline Potassium & 1079.9 & 1205.2 & 1341.6 & 1048.9 & 1219.8 & 1401.2 & 544.6 & 643.1 & 784.0 & 891.1 & 1102.0 & 1465.2 \\
\hline Phosphorus & 673.5 & 731.3 & 812.3 & 651.7 & 734.7 & 869.2 & 774.0 & 892.4 & 1132.4 & 686.9 & 802.6 & 1166.1 \\
\hline Iron & 4.7 & 5.2 & 5.7 & 5.6 & 5.7 & 6.1 & 4.9 & 5.7 & 10.6 & 5.6 & 6.0 & 12.2 \\
\hline Zinc & 4.4 & 4.9 & 5.5 & 4.8 & 5.3 & 6.0 & 5.3 & 5.9 & 8.4 & 5.1 & 6.0 & 15.9 \\
\hline Copper & 1.5 & 1.6 & 1.9 & 1.6 & 1.8 & 2.0 & 1.8 & 1.9 & 2.6 & 0.1 & 0.4 & 1.4 \\
\hline
\end{tabular}

Abbreviations: AMM Apis mellifera mellifera, AMC Apis mellifera carnica, AML Apis mellifera ligustica, AMB Apis mellifera buckfast, PP prepupa, EP early pupa, LP late pupa, $A$ adult

Data obtained for AML and AMB: Ghosh et al. 2020c; AMM and AMC: Ghosh et al. 2021b

dietary allowance (RDA), particularly with regard to phosphorus, iron, and zinc, can be satisfied by the daily consumption of $100 \mathrm{~g}$ of bee pupae (Fig. 3a and b). Similarly, calculations based on the content of minerals in
$100 \mathrm{~g}$ of A. mellifera mellifera and A. m. carnica drones, consumed irrespective of developmental stage, show the RDA for copper and phosphorus is met. It also satisfies 58.8 to $76.3 \%$ of the RDA for iron for adult male

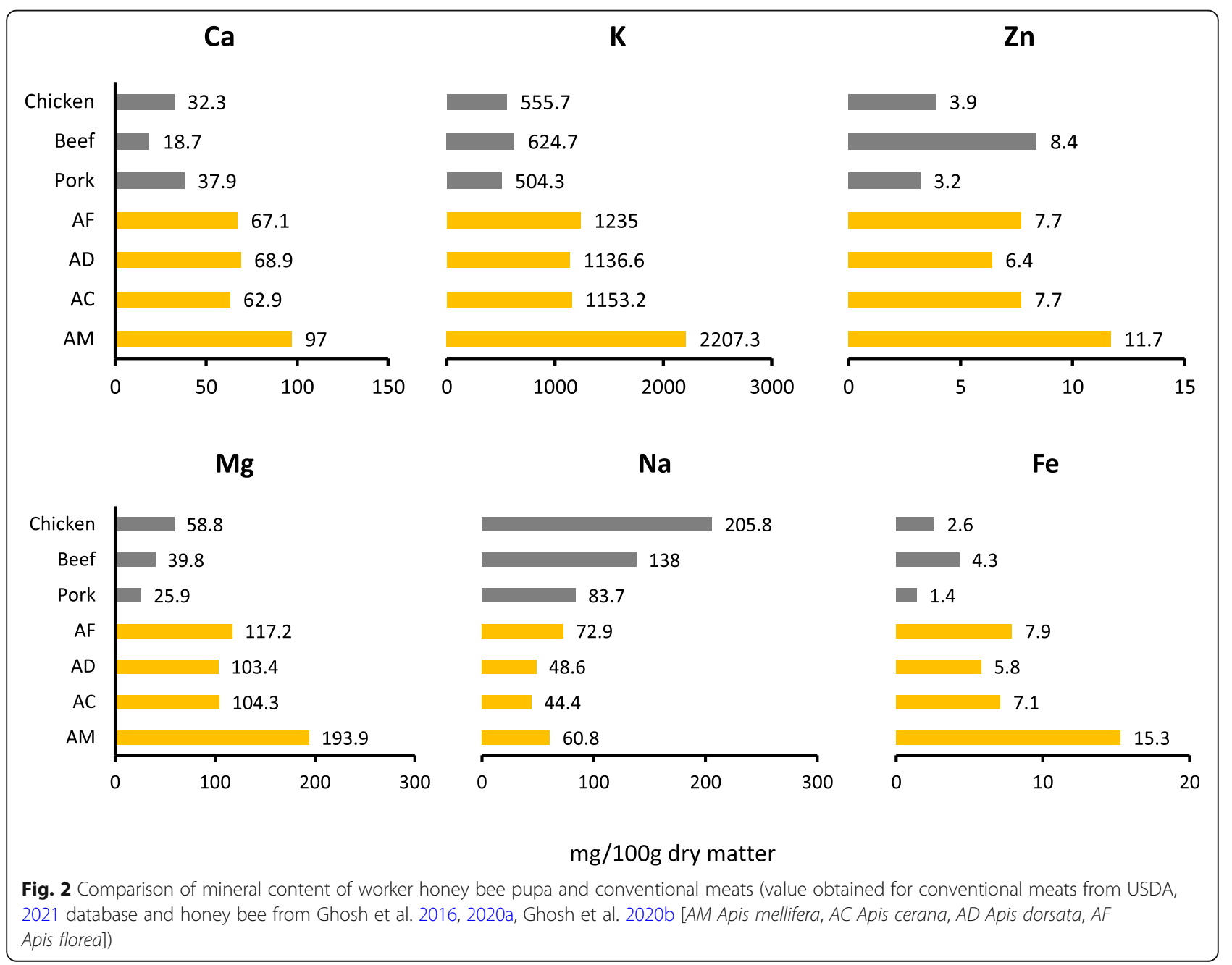




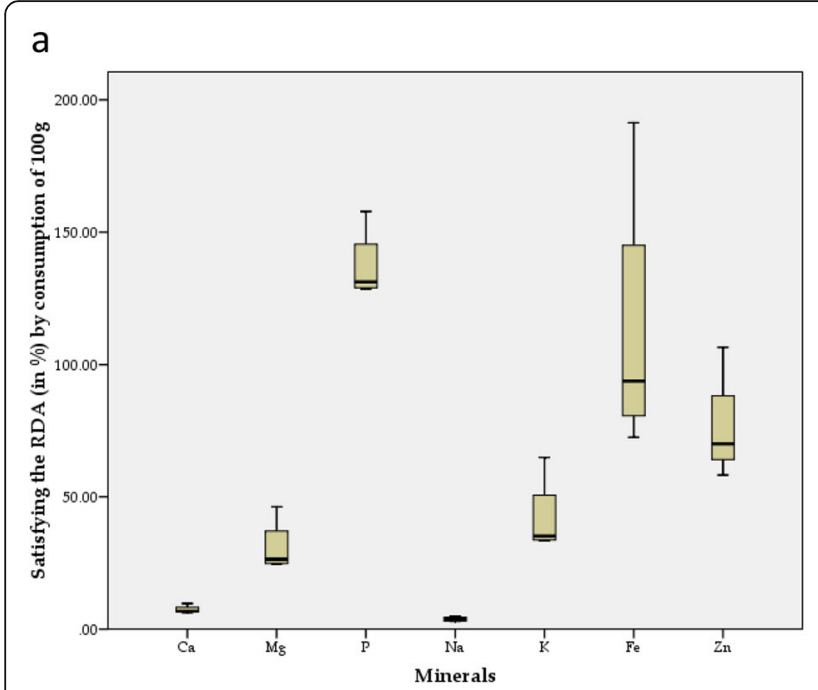

b

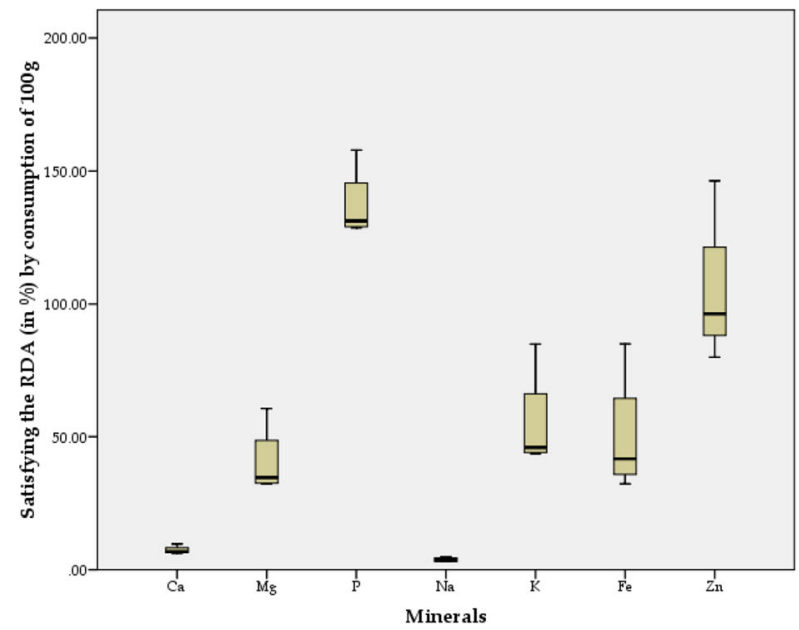

Fig. 3 Satisfying the RDA (in \%) in (a) males and (b) females by consuming $100 \mathrm{~g}$ of dry honey bee worker pupae belonging to the genus Apis

subjects, while less, namely, 26.1 to $33.9 \%$ of RDA for females as the latter have a greater need for iron than males. In contrast, RDA for zinc is higher for males than females, and therefore, 40 to $54.5 \%$ of the RDA would be available to male subjects by consuming $100 \mathrm{~g}$ of drones while 55 to $75 \%$ of the RDA would fulfill the requirement for females. In total, 30.9 to $53.9 \%$ of the RDA can be attained with regard to potassium (Ghosh et al., 2021b). However, worrying increases of lead $(\mathrm{Pb})$ and cadmium levels in honey bees of heavily industrialized areas have been noticed (Abhik Gupta, personal communication) and this is one aspect to be carefully monitored when recommending bees and bee brood as a food item for humans.

\section{Vitamin content}

Vitamins, a chemically disparate group of compounds, are essential micronutrients playing a variety of functions including as coenzymes, antioxidants, cell differentiation, and visual pigments. Table 7 represents the vitamin contents of honey bees. Hocking and Matsumura (1960) estimated vitamin A (larva, 89-119; pupa, 49.3-53.3 IU per g wet weight) and D (larva, 6130-7430; pupa, 5070-5260 IU per g wet weight) contents of honey bee worker mature larvae and pupae. Finke (2005) reported the presence of all the vitamins in honey bee brood.

\section{Pharmacological functions}

Honey bees are not just a nutritious source of food but also exhibit several pharmacological functions. $\mathrm{Hu}$ and Li (2001) demonstrated the anti-tumor and anti-aging potential of worker larvae, pupae, and queen larvae.
Comparisons between a control and homogenate (25 $\mathrm{mg} / \mathrm{mL}$ ) of worker larvae, pupae, and queen larvae showed that in mice tumor growth was inhibited up to $60.9,64.4$, and $59.8 \%$ respectively. To measure or gauge the anti-aging potential, superoxide dismutase (SOD) and malondialdehyde (MDA) contents were determined in the brain, liver, and blood of rats and found in significantly higher amounts in the experimental groups than the control. The experimental group given bee brood also showed significantly higher T-lymphocyte transformation and thymus indices.

A study by Vasilenko et al. (2002) demonstrated the effect of drone brood under chronic hyperlipidaemia conditions in rats. Lyophilized drone larvae exhibited pronounced hypolipidemic effects including acceleration of cholesterol conversion into bile acids, retardation of adrenal reaction, and stabilization of biological membranes. Lyophilized drone larvae also exhibited the ability to improve phagocytosis, levels of lysozyme and total bilirubin, increase the activity of blood serum and $\beta$ lysine level, and reduce alanine amino transferase and alkaline phosphatase activity in rats with $\mathrm{CCl}_{4}$ induced hepatitis (Vasilenko et al. 2005). Androgenic as well as oestrogenic effects were investigated on castrated male rats and female Sprague-Dawley rats respectively (Seres et al. 2013). Kim et al. (2020b) reported the anti-oxidant, i.e., free radical scavenging activity of drone pupa extract. The study suggested that freeze-dried drone pupae are not only rich in nutritional ingredients but also appreciable for their functional properties like anti-oxidant activity. Kim et al. (2020c) evaluated the efficacy of drone pupal extracts in slowing down hair loss in humans. In most of the cases, investigations such as thee 
Table 7 Vitamin content $(\mu \mathrm{g} / 100 \mathrm{~g}$, if not mentioned otherwise) of honey bee

\begin{tabular}{|c|c|c|c|c|c|c|}
\hline & $\begin{array}{l}\text { Worker larvae (9th } \\
\text { day) }\end{array}$ & $\begin{array}{l}\text { Worker pupae (19th } \\
\text { day) }\end{array}$ & Bee brood ${ }^{a}$ & Mature larvae & Pupae & $\begin{array}{l}\text { Drone } \\
\text { pupae }\end{array}$ \\
\hline Vitamin A & 1.32 & 7.41 & $\begin{array}{l}<1000 \mathrm{IU} / \\
\mathrm{kg}\end{array}$ & $89-119 \mathrm{IU} / \mathrm{g}$ & $49.3-53.3 \mathrm{IU} / \mathrm{g}$ & ND \\
\hline Vitamin B1 (thiamine) & 0.94 & 3.27 & 410 & -- & -- & 1550 \\
\hline Vitamin B2 (riboflavin) & 184 & 251 & 910 & -- & -- & 2930 \\
\hline Vitamin B3 (niacin) & -- & -- & 3670 & -- & -- & -- \\
\hline $\begin{array}{l}\text { Vitamin B5 (pantothenic } \\
\text { acid) }\end{array}$ & -- & -- & 1190 & -- & -- & -- \\
\hline Vitamin B6 (pyridoxine) & -- & -- & 120 & -- & -- & ND \\
\hline Vitamin B7 (biotin) & -- & -- & 0.023 & -- & -- & ND \\
\hline Vitamin B9 (folic acid) & -- & -- & $<0.006$ & -- & -- & ND \\
\hline Vitamin B12 & -- & -- & $<0.12$ & - & -- & ND \\
\hline Vitamin C & 4020 & 4350 & 3800 & -- & -- & 14920 \\
\hline Vitamin D & 390 & 410 & $<251 \mathrm{lU} / \mathrm{kg}$ & $\begin{array}{l}\text { 6130-7430 IU/ } \\
\mathrm{g}\end{array}$ & $\begin{array}{l}5070-5260 \mathrm{IU} / \\
\mathrm{g}\end{array}$ & ND \\
\hline Vitamin E & 0.87 & 1.10 & $<5 \mathrm{IU} / \mathrm{kg}$ & -- & -- & 6060 \\
\hline Choline & -- & -- & 168.4 & -- & -- & -- \\
\hline
\end{tabular}

Data obtained for worker larvae (9th day) and worker pupae (19th day): Hu and Li 2001; bee brood: Finke 2005; mature larvae and pupae: Hocking and Matsumura 1960; drone pupae: Kim et al., 2020b

${ }^{\mathrm{a}}$ Data calculated as $\mu \mathrm{g} / 100 \mathrm{~g}$ from original value provided in respective papers except the value provided as IU/kg

ND not detected

'-' = not investigated

are confined to A. mellifera and their drones in particular. It is necessary to examine the other honey bee species in the context.

\section{Honey bee as a potential animal feed}

Recently, European Union (EU) permits insect protein in poultry and pig feed by the regulation EU 2021/ 1372 and this truly opens a provision using honey bees as animal feed. Yucel et al. (2011) demonstrated that administration of apilarnil (drone bee larvae) in broiler (Ros-308 genotype broilers aged 21 days) showed better feed conversion and androgenic effects, including the length of the comb and width of the wattle. Another study by Muraviev and Kalatzinskaja (2014) demonstrated increased egg production and higher quality in drone homogenate fed hens (cf. Sawczuk et al. 2019). Administration of ethanolic extract of drone brood homogenate to 2 to 4 months old male pigs showed significant improvements in reproductive qualities including the weight of seminal glands and a rise in epididymis volume (Bolatovna et al. 2015; cf. Sawczuk et al. 2019). Another study on stud rams by Shoinbayeva et al. (2017) also demonstrated androgenic effects, i.e., quality of semen including ejaculation volume, germ cell density, and mobility, all exhibiting improvements following treatment with drone brood homogenate.

\section{Conclusion}

Paying attention to the competent nutrient composition of honey bee brood, pupae and prepupae in particular, could pave the way to accept these insects as a potential source of human nutrition as well as animal feed. Drone brood in particular is an ideal candidate for use as a food or food ingredient. However, ecological and environmental issues, including quantity and quality of the bees' nutrition, can influence as with other insects (MeyerRochow et al. 2021), the chemical composition of the honey bee, its body weight, and health status. These issues will have to be a subject for further investigation. Even the estimation of vitamins and detailed account of carbohydrates in connection with different developmental stages of honey bees still remain largely unexplored and a task for the future. Additionally, a dossier for the development of a production system maintaining hygiene and sanitation is needed and monitoring the effects of pesticides and antibiotics at regular intervals is a necessity to ensure the safety of the product. Besides, an investigation of the precise functional properties that the ingested food has on the consumer is required in order to explore the most potent and useful bioactive compounds in bee brood.

\section{Abbreviations}

AM: Apis mellifera; AC: Apis cerana; AD: Apis dorsata; AF: Apis florea; AMM: Apis mellifera mellifera; AMC: Apis mellifera carnica; AML: Apis mellifera ligustica: AMB: Apis mellifera buckfast; P: Pupa; A: Adult; PP: Prepupa; EP: Early pupa; 
LP: Late pupa; A: Adult; SAA: Sulphur containing amino acids; AAA: Aromatic amino acids; SFA: Saturated fatty acids; MUFA: Monounsaturated fatty acids; PUFA: Polyunsaturated fatty acids; FAO: Food and Agriculture Organization of the United Nations; WHO: World Health Organization; UNU: United Nations University

\section{Acknowledgements}

This study was partly supported by the BSRP through the National Research Foundation of Korea (NRF), Ministry of Education (NRF-2018 R1 A6 A1 A03024862).

\section{Authors' contributions}

All authors have participated in the research design and manuscript writing. SG analyzed chemically, reviewed the literature, and wrote and prepared the original draft manuscript. VBM and CJ reviewed and revised the manuscript. CJ supervised the research and involved in project administration. All authors have read the final version of the manuscript.

\section{Funding}

The study was funded by BSRP through the National Research Foundation of Korea (NRF), Ministry of Education (NRF-2018 R1 A6 A1 A03024862) and RDA agenda project on honey bee PJ01574604.

\section{Availability of data and materials}

Not applicable

\section{Declarations}

\section{Ethics approval and consent to participate}

Not applicable

\section{Consent for publication}

Not applicable

\section{Competing interests}

The authors declare that they have no competing interests.

\section{Author details}

${ }^{1}$ Agriculture Science and Technology Research Institute, Andong National University, Andong, Republic of Korea. ${ }^{2}$ Department of Ecology and Genetics, Oulu University, Oulu, Finland. ${ }^{3}$ Department of Plant Medical, Andong

National University, Andong, Republic of Korea.

Received: 10 October 2021 Accepted: 18 November 2021

Published online: 09 December 2021

\section{References}

Arrese EL, Soulages JL. Insect fat body: energy, metabolism, and regulation. Annu Rev Entomol. 2010;55(1):207-25. https://doi.org/10.1146/annurev-ento-1124 08-085356.

Bamidele JA, Idowu AB, Ademolu K, Osipitan AA. Nutritional composition of Apis mellifera adansoniiL. (Hymenoptera: Apidae) from three ecological zones of Nigeria. J Apicul Res. 2021;60(3):445-56. https://doi.org/10.1080/00218839.2 021.1874709 .

Bolatovna KS, Rustenov A, Eleuqalieva N, Omirzak T, Akhanov UK. Improving reproductive qualities of pigs using the drone brood homogenate. Biol Med (Aligarh). 2015;7(2):2 3 BM-091-15.

Boot RG, Renkema GH, Verhoek M, Strijland A, Bliek J, de Meulemeester TM, et al. The human chitotriosidase gene. Nature of inherited enzyme deficiency. J Biol Chem. 1998;273(40):25680-5. https://doi.org/10.1074/jbc.273.40.25680.

Chang NC, Hung SI, Hwa KY, Kato I, Chen JE, Liu CH, et al. A macrophage protein, Ym1, transiently expressed during inflammation is a novel mammalian lectin. J Biol Chem. 2001;276(20):17497-506. https://doi.org/10.1074/jbc.M0104172 00.

Cherry RH. Use of insects by Australian Aborigines. Am Entomol. 1991;37(1):8-13. https://doi.org/10.1093/ae/37.1.8.

d'Errico F, Backwell L, Villa P, Degano I, Lucejko JJ, Bamford MK, et al. Early evidence of San material culture represented by organic artefacts from Border cave, South Africa. Proc Natl Acad Sci U S A. 2012:109(33):13214-9. https://doi.org/10.1073/pnas.1204213109.
De Groot AP. The influence of temperature and kind of food of the increase in the nitrogen content of the young worker honeybee (Apis mellifera L.). 45th communication of the "Werkgemeenschapvoor Endocrinologie", part of the National Council for Agricultural Research T.N.O. Proc K Akad Wet Ser C. 1950; Available from: https://www.dwc.knaw.nl/DL/publications/PU00018807. pdf, accessed $15^{\text {th }}$ Sept. 2021.

DeFoliart G. Insects as human food. Crop Prot. 1992;11(5):395-9. https://doi.org/1 0.1016/0261-2194(92)90020-6.

DeFoliart G. Edible insects as minilivestock. Biodivers Conserv. 1995;4(3):306-21. https://doi.org/10.1007/BF00055976.

Draczynski Z. Honeybee corpses as an available source of chitin. J Appl Polym Sci. 2008;109(3):1974-81. https://doi.org/10.1002/app.28356.

FAO (Food and Agriculture Organization of the United Nations). Dietary protein quality evaluation in human nutrition. Rome, Italy: FAO; 2013.

Finke MD. Nutrient composition of bee brood and its potential as human food. Ecol Food Nutr. 2005;44(4):257-70. https://doi.org/10.1080/036702405001872 78.

Gessain M, Kinzler T. Mieletlnsectes à miel chez les Bassari et D'autres Populations du Sénégal Oriental [Honey and Honey Making Insects in the Bassari and Other Populations of Eastern Senegal]. In L'hommeetL'annimal; PujolR, Ed.; Premier Colloqued'Ethnozoologie: Paris, France, 1975; pp. 247-254.

Ghosh S, Chuttong B, Burgett M, Meyer-Rochow VB, Jung C. Nutritional value of brood and adult worker of the Asia honeybee species Apis cerana and Apis dorsata. In: Mariod AA, editor. In African edible insects as alternative source of food, oil, protein and bioactive components. Springer, Cham; 2020a. p. 265-73. https://doi.org/10.1007/978-3-030-32952-5_19.

Ghosh S, Gahukar RT, Meyer-Rochow VB, Jung C. Future prospects of insects as biological resource in India: potential biological products utilizing insects with reference to the frontier countries. Entomoll Res. 2021a;51(5):209-29. https://doi.org/10.1111/1748-5967.12507.

Ghosh S, Herren P, Meyer-Rochow VB, Jung C. Nutritional composition of honey bee drones of two subspecies relative to their pupal developmental stages. Insects. 2021 b;12(8):759. https://doi.org/10.3390/insects12080759.

Ghosh S, Jung C, Chuttong B, Burgett M. Nutritional aspects of the dwarf honeybee (Apsi florea F.) for human consumption. In: Abrol DP, editor. In The future role of dwarf honeybees in natural and agricultural systems. Boca Raton, FL: CRC Press; 2020b. p. 137-45.

Ghosh S, Jung C, Meyer-Rochow VB. Nutritional value and chemical composition of larvae, pupae, and adults of worker honey bee, Apis mellifera ligustica as a sustainable food source. J Asia Pac Entomol. 2016;19:487-95. https://doi. org/10.1016/j.aspen.2016.03.008.

Ghosh S, Sohn H-Y, Pyo S-J, Jensen AB, Meyer-Rochow VB, Jung C. Nutritional composition of Apis mellifera drones from Korea and Denmark as a potential sustainable alternative food source: comparison between developmental stages. Foods. 2020c;9(4):389. https://doi.org/10.3390/foods9040389.

Haddad L. Women's status: levels, determinants, consequences for malnutrition, interventions, and policy. Asian Dev Rev. 1999;17(1-2):96-131.

Haydak MH. Changes with age in weight and nitrogen content of honeybees. Bee World. 1959;40(9):225-9. https://doi.org/10.1080/0005772X.1959.1109673 5 .

Hocking B. Bees knees. Proc Alta Entomol Soc. 1957:4:17.

Hocking B, Matsumura F. Bee brood as food. Bee World. 1960;41(5):113-20. https://doi.org/10.1080/0005772X.1960.11096777.

Hollak CEM, van Weely S, van Oers MHJ, Aerts JM. Marked elevation of plasma chitotriosidase activity. A novel hallmark of Gaucher disease. J Clin Investig. 1994;93(3):1288-92. https://doi.org/10.1172/JCl117084.

Hu F, Li Y. Nutritive value and pharmacological actions of Italian worker bee larvae and pupae. Proceedings of the 37th International Apicultural Congress, Apimondia. Durban: Produced by: Document Transformation Technologies; 2001. ISBN: 0-620-27768-8. Available from: https://www.a pimondia.com/docs/congress/2001/Papers/294.pdf. Accessed 2 Apr 2021.

Jensen AB, Evans J, Jonas-Levi A, Benjamin O, Martinez I, Dahle B, et al. Standard methods for Apis mellifera brood as human food. J Apicul Res. 2019;58(2):128. https://doi.org/10.1080/00218839.2016.1226606.

Kim J-E, Kim D-I, Kim H-J, Kim S-Y, Lee Y-B, Moon J-H, et al. Characteristics of hydrolysis of protein in drone pupa (Apis mellifera L.). J Apiculture. 2020a; 35(3):169-77. https://doi.org/10.17519/apiculture.2020.09.35.3.169.

Kim J-E, Kim D-I, Koo H-Y, Kim H-J, Kim S-Y, Lee Y-B, et al. Evaluation of honey bee (Apis mellifera L.) drone pupa extracts on the improvement of hair loss. J Apiculture. 2020c:35(3):179-88. https://doi.org/10.17519/apiculture.2020.09.3 5.3.179. 
Kim J-E, Kim D-I, Koo H-Y, Kim H-J, SOY K, Lee Y-B, et al. Analysis of nutritional compounds and antioxidant effect of freeze-dried powder of the honey bee (Apis mellifera L.) drone (pupal stage). Korean J Appl Entomol. 2020b;59(3): 265-75. https://doi.org/10.5656/KSAE.2020.08.0.029.

Kim SG, Woo SO, Bang KW, Jang HR, Han SM. Chemical composition of drone pupa of Apis mellifera and its nutritional evaluation. J Apiculture. 2018;33(1): 17-23. https://doi.org/10.17519/apiculture.2018.04.33.1.17.

Kimura $\mathrm{AH}$. Hidden hunger, gender and the politics of smarter foods. Ithaca, New York: Cornell University Press; 2013. p. 1-42.

Kipkoech C, Kinyuru JN, Imathiu S, Meyer-Rochow VB, Roos N. Invitro study of cricket chitosan's potential as a prebiotic and promoter of probiotic microorganisms to control pathogenic bacteria in the human gut. Foods. 2021;10(10):2310. https://doi.org/10.3390/foods10102310.

Klein A-M, Vaissière BE, Cane JH, Steffan-Dewenter I, Cunningham SA, Kremen C, et al. Importance of pollinators in changing landscapes for world crops. Proc R Soc B. 2007;274(1608):303-13. https://doi.org/10.1098/rspb.2006.3721.

Lopez-Santamarina A, Mondragon AC, Lamas A, Miranda JM, Franco CM, Cepeda A. Animal-origin prebiotics based on Chitin: an alternative for the future? A critical review. Foods. 2020;9(6):782. https://doi.org/10.3390/foods9060782.

Mbata KJ. Traditional use of arthropods in Zambia. I. The food insects. Food Insects Newsletter. 1995;8:5-7.

Meyer-Rochow VB, Gahukar RT, Ghosh S, Jung S. Chemical composition, nutrient quality and acceptability of edible insects are affected by species, developmental stage, gender, diet, and processing method. Foods. 2021;10: 1036. https://doi.org/10.3390/foods 10051036.

Micheu S, Crailsheim K, Leonhard B. Importance of proline and other amino acids during honeybee flight. Amino Acids. 2000;18:157-75. https://doi.org/10.1 007/s007260050014.

Millward DJ, Fereday A, Gibson N, Pacy PJ. Aging, protein requirements, and protein turnover. Am J Clin Nutr. 1997;66(4):774-86. https://doi.org/10.1093/a $\mathrm{jcn} / 66.4 .774$.

Muraviev DW, Kalatzinskaja AM. Drone homogenate and hens productivity. Viestnik Kazanskovo GAU. 2014;1:132-4.

Murray SS, Schoeninger MJ, Bunn HT, Pickering TR, Marlett JA. Nutritional composition of some wild plant foods and honey used by Hazda foragers of Tanzania. J Food Compos Anal. 2001;14(1):3-13. https://doi.org/10.1006/jfca.2 000.0960.

Muzzarelli RAA, Boudrant J, Meyer D, Manno N, DeMarchis M, Paoletti MG. Current views on fungal chitin/chitosan, human chitinases, food preservation, glucans, pectins and inulin: a tribute to Henri Braconnot, precursor of the carbohydrate polymers science, on the chitin bicentennial. Carbohydr Polym. 2012:87(2):995-1012. https://doi.org/10.1016/j.carbpol.2011.09.063.

Nemtsev SV, Zueva OU, Khismatoullin RG, Khismatoullin MR, Varlamov VP. Bees as potential source of chitosan. Proceedings of the $37^{\text {th }}$ International Apicultural Congress, 28 Oct-1 Nov 2001; Durban, South Africa. Available from: https:// www.apimondia.com/docs/congress/2001/Papers/162.pdf accessed $24 \mathrm{Sep}$ 2021.

Nemtsev SV, Zueva OY, Khismatullin MR, Albulov Al, Varlamov VP. Isolation of chitin and chitosan from honeybees. Appl Biochem Microbiol. 2004;40(1):3943.

Onore G. A brief note on edible insects in Ecuador. Ecol Food Nutr. 1997;36(2-4): 277-85. https://doi.org/10.1080/03670244.1997.9991520.

Ozimek L, Sauer WC, Kozikowski V, Ryan JK, Jørgensen H, Jelen P. Nutritive value of protein extracted from honey bees. J Food Sci. 1985;50(5):1327-9. https:// doi.org/10.1111/j.1365-2621.1985.tb10469.x.

Paoletti MG, Norberto L, Cozzarini E, Musumeci S. Role of chitinase in human stomach for chitin digestion: AMCase in the gastric digestion of chitin and chitotrisidase in gastric pathologies. In: Musumeci S, Paoletti MG, editors. Binomium chitin-chitinase: Recent issues. New York: Nova Biomedical Books; 2009.

Paoletti MG, Norberto L, Damini R, Musumeci S. Human gastric juice contains chitinase that can degrade chitin. Ann Nutr Metab. 2007;51:244-51. https:// doi.org/10.1159/000104144

Paoli PP, Donley D, Stabler D, Saseendranath A, Nicolson SW, Simpson SJ, et al. Nutritional balance of essential amino acids and carbohydrates of the adult worker honeybee depends on age. Amino Acids. 2014;46:1449-58. https:// doi.org/10.1007/s00726-014-1706-2.

Ramos-Elorduy J, Moreno JMP, Prado EE, Perez MA, Otero JL, de Guavara OL. Nutritional value of edible insects from the state of Oaxaca, Mexico. J Food Compos Anal. 1997;10(2):142-57. https://doi.org/10.1006/jfca.1997.0530.
Roffet-Salque M, Regert M, Evershed RP, Outram AK, Cramp LJE, Decavallas O, et al. Widespread exploitation of the honeybee by early Neolithic farmers. Nature. 2015;527:226-30. https://doi.org/10.1038/nature15757.

Ruttner F. Biogeography and taxonomy of honeybees. Berlin, Germany: SpringerVerlag; 1988. p. 284p.

Sawczuk R, Karpinska J, Miltyk W. What do we need to know about drone brood homogenate and what is known. J Ethnopharmacol. 2019;245:111581. https://doi.org/10.1016/j.jep.2018.10.042.

Seres AB, Ducza E, Báthori M, Hunyadi A, Béni Z, Dékány M, et al. 2013. Raw drone milk of honeybees elicits uterotrophic effects in rats: evidence for estrogenic activity. J Med Food. 2013;16(5):404-9. https://doi.org/10.1089/ jmf.2012.0232.

Shoinbayeva KB, Omirzak T, Bigara T, Abubakirova A, Dauylbay A. Biologically active preparation and reproductive function of stud rams. Asian J Pharm. 2017;11(3):184-91.

Strauss J. Die chemische Zusammensetzung der Arbeitsbienen und Drohnen während ihrer verschiedenen Entwicklungsstadien. Zoo Biol. 1911;56:347-97.

Torre-Bueno JRD. Why not eat insects? Bull Brooklyn Entomol Soc. 1944;39:12231.

USDA Database on Nutrient Content of Food. Available online: http://www.data. nal.usda.gov accessed on 2 April 2021.

Vasilenko YK, Klimova OV, Lazaryan DS. Biological effect of drone brood under chronic hyperlipidemia conditions. Pharm Chem J. 2002;36:434-6. https://doi. org/10.1023/A:1021214728006.

Vasilenko YK, Klishina II, Lazaryan DS. A comparative study of the immunotropic and hepatotropic action of beekeeping products in rats with drug-induced hepatitis. Pharm Chem J. 2005;39:319-22. https://doi.org/10.1007/s11094-0050144-6.

Wongsiri S, Lekprayoon C, Thapa R, Thirakupt K, Rinderer TE, Sylvester HA, et al. Comparative biology of Apis andreniformis and Apis florea in Thailand. Bee World. 1997;78:23-35. https://doi.org/10.1080/0005772X.1997.11099328.

Yucel B, Acikgoz Z, Bayraktar H, Seremet C. The effects of Apilarnil (drone bee larvae) administration on growth performance and secondary sex characteristics of male broilers. J Anim Vet Adv. 2011;10(17):2263-6.

Zhi-Yi L. Insects as food in China. Ecol Food Nutr. 1997;36(2-4):201-7. https://doi. org/10.1080/03670244.1997.9991515.

\section{Publisher's Note}

Springer Nature remains neutral with regard to jurisdictional claims in published maps and institutional affiliations.

Ready to submit your research? Choose BMC and benefit from:

- fast, convenient online submission

- thorough peer review by experienced researchers in your field

- rapid publication on acceptance

- support for research data, including large and complex data types

- gold Open Access which fosters wider collaboration and increased citations

- maximum visibility for your research: over $100 \mathrm{M}$ website views per year

At BMC, research is always in progress.

Learn more biomedcentral.com/submissions 